К.О. Бобкович, Т.О. Ілащук, Н.М. Малкович

\title{
ВИКОРИСТАННЯ КОМБІНОВАНИХ ПРЕПАРАТІВ РОСЛИННОГО ПОХОДЖЕННЯ ДЛЯ ЗАПОБІГАННЯ ГОСПІТАЛІЗАЦІЙ ПАЦІЕНТІВ ІЗ ХРОНІЧНОЮ СЕРЦЕВОЮ НЕДОСТАНІСТЮ ТА ФІБРИЛЯЦІЕЮ ПЕРЕДСЕРДЬ
}

Вищий державний навчальний заклад України «Буковинський державний медичний університет», м. Чернівці

Резюме. Обстежено 45 хворих із хронічною серцевою недостатністю (ХCH) IІА-ІІБ стадії, ІІІ функціонального класу та постійною тахісистолічною фібриляцією передсердь (ФП). Виявлено, що додаткове призначення хомвіокорину-N сприяє більш швидкому регресу клінічних симптомів, зменшенню частоти серцевих скорочень, потреби в повторних госпіталізаціях, не викликаючи небажаних побічних ефектів.

Ключові слова: хронічна серцева недостатність, фібриляція передсердь, хомвіокорин-N, лікування.
Вступ. ХСН, як наслідок більшості захворювань серцево-судинної системи, посідає чільне місце в структурі загальної захворюваності та смертності населення [2]. Водночас підвищення рівня смертності, ризику інсультів та системної тромбоемболії ускладнює перебіг ФП [4]. Частота поєднання ФП і ХСН становить більш ніж $1 \%$ загальної популяції, стрімко зростає з віком та 3 погіршанням функціонального класу ХCH [6] i становить при II ФК (NYHA) 10 \%, при IV ФК близько $40 \%$. При цьому ФП може бути як наслідком, так і єдиною причиною ХСН [3].

На даний момент не існує загального правила медикаментозної корекції ФП. Згідно $з$ даними піддослідження програми DIAMOND, відновлення та збереження синусового ритму асоціювалося 3 достовірним зменшенням смертності [5]. Водночас у низці досліджень (PIAF, AFFIRM, RACE, STAF, HOT CAFE, AF CHF), проведених із метою порівняння результатів лікування пацієнтів, яким відновлювали і підтримували синусовий ритм чи зменшували частоту серцевих скорочень (ЧСС) при збереженій ФП, не виявили прогностичної переваги стратегії збереження синусового ритму [7]. Безумовно, ці протиріччя поглиблюються в пацієнтів із XCH III -IV ФК із систолічною дисфункцією ЛШ.

Одним із важливих напрямів лікування в пацієнтів із ХCH та постійною тахісистолічною ФП є застосування серцевих глікозидів. Сучасні рекомендації включають лише препарат дигоксин, тривале використання якого часто ускладнене через велику кількість побічних ефектів, особливо за умови гіпокаліємії на тлі прийому сечогінних засобів, у тому числі і через утруднений контроль на амбулаторному етапі лікування. Певною альтернативою в даному напрямку є використання комбінованих препаратів рослинного походження, що містять глікозидні чинники.

Мета дослідження. Вивчити вплив препарату хомвіокорин-N на клінічний перебіг, функціонально-гемодинамічні показники серця та потребу в повторних госпіталізаціях пацієнтів із ХCH та ФП на амбулаторному етапі лікування.

Матеріал і методи. Нами обстежено 45 пацієнтів віком від 63 до 85 років із $\mathrm{XCH}$ ішемічно- го генезу IIA-ІІБ ст. III ФК та постійною тахіситолічною формою ФП, які на стаціонарному етапі лікування отримували однакову терапію (бісопролол, лізиноприл, спіронолактон, статини, ацетилсаліцилову кислоту per os та дигоксин, аспаркам і фуросемід парентерально) та на амбулаторному етапі були розподілені на три групи. Пацієнти I групи (12 осіб) продовжували прийом таблетованих препаратів із стаціонарного етапу та фуросемід з аспаркамом за потребою. У II групі (15 осіб) додатково призначали препарат дигоксин у дозуванні 0,25 мг на добу курсами по п'ять днів, потім два дні перерва. Пацієнти III групи (18 осіб) замість дигоксину приймали хомвіокорин-N по 15 крапель тричі на день. Хомвіокорин-N - комбінований препарат рослинного походження виробництва фірми ХомвіораАрцнайміттель Др. Хагедорн Гмбх і Ко (м.Мюнхен, Німеччина), до складу якого входять такі компоненти, як горицвіт весняний, конвалія травнева, плоди глоду, морська цибуля, золотушник звичайний.

Оцінка динаміки скарг пацієнтів, що проводилася за опитувальною 5-бальною шкалою, показників ЕКГ та ехокардіографії проводилася через один і три місяці лікування. Частота загострень, потреба в повторній госпіталізації та тривалість ремісії оцінювалася впродовж 1-го року.

Критерії виключення 3 дослідження: АВблокада II та III ступенів, синоатріальна блокада, брадикардія, гемодинамічно значущий мітральний або аортальний стеноз, гіперчутливість до препарату, за даними анамнезу, виражена печінкова та ниркова недостатність, за даними лабораторних аналізів, психічні розлади, гострі інфекційні захворювання, гострі форми ішемічної хвороби серця: інфаркт міокарда, нестабільна стенокардія.

Статистичну обробку отриманих результатів проводили 3 визначенням t-критерію Стьюдента за програмою "Biostat" [1].

Результати дослідження та їх обговорення. Нами досліджено, що впродовж 3-місячного лікування в пацієнтів II та III досліджуваних груп регресу клінічних проявів - болю в ділянці серця,

(C) К.О. Бобкович, Т.О. Ілащук, Н.М. Малкович, 2015 


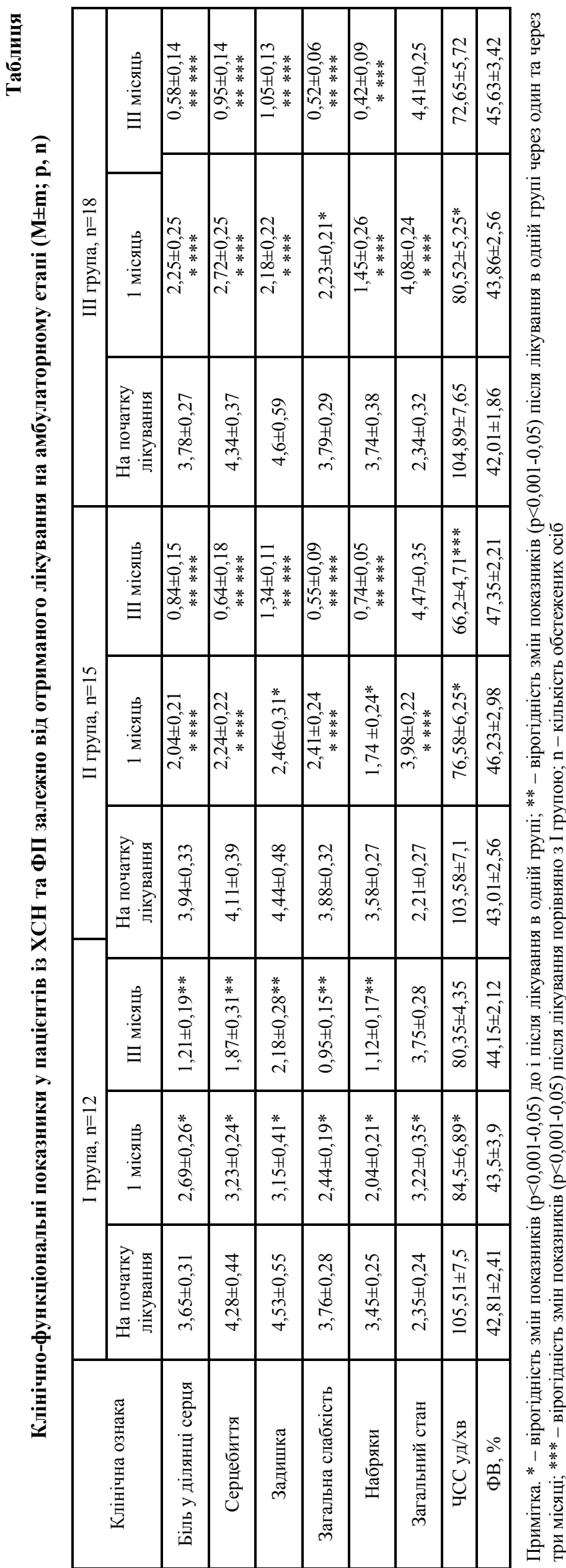

серцебиття, задишки, загальної слабкості, набряків, дратівливості - вдалося досягнути на 2-3 дні раніше (табл.). Зокрема за додаткового прийому дигоксину обстежувані відмічали суттєве зменшення серцебиття, що пояснюється вираженою негативною хронотропною та позитивною ізотропною діями препарату. Ад'ювантне призначення хомвіокорину$\mathrm{N}$ зумовлювало зниження серцебиття в меншій мірі порівняно з II групою, проте $з$ вірогідною різницею до осіб І досліджуваної групи. Водночас у цих пацієнтів відмічався більш стійкий регрес задишки та набряків, що, ймовірно, зумовлено наявністю в складі препарату, окрім глікозидних чинників, компонентів із діуретичним ефектом (золотушник звичайний та морська цибуля).

При оцінці частоти серцевих скорочень, яка $є$ основним показником ефективності лікування в осіб із постійною формою ФП, виявлено вірогідне та стійке зниження ЧСС у групах за додаткового прийому препаратів із глікозидним ефектом, особливо на тлі дигоксину. Так, упродовж 1-го місяця лікування в II групі ЧСС знизилося на 26,06 \% та $34 \%$ після 3-го місяця лікування з вірогідною різницею до показників I групи $(\mathrm{p}<0,05)$. За додаткового прийому хомвіокоринуN ЧСС знизилася на 23,21 \% після 1-го та на 30,72 \% після 3-го місяця лікування, причому зміни носили тенденційний характер порівняно з I групою.

Проте в частини пацієнтів II групи прийом дигоксину потребував корекції в напрямку зниження добової дози спочатку до 0,125 мг, а потім 0,0625 мг та відміни препарату у $18 \%$ осіб у перший місяць спостереження і ще у $35 \%$ - у третій, у зв'язку з розвитком побічних ефектів (брадикардії, коритоподібної депресії сегмента ST). У 30 \% пацієнтів виникала передсердна та шлуночкова екстрасистолії. Додатковий прийом хомвіокорину-N не потребував корекції на амбулаторному етапі, оскільки побічних проявів не було зареєстровано. Це можна пояснити меншими дозами глікозидних чинників у фітопрепараті та його м'яким діуретичним ефектом, за рахунок якого порівняно з II групою зменшувалася потреба пацієнтів у петльових діуретиках, чим знижувався ризик гіпокаліємії і аритмії.

При оцінці показників ехокардіографії в усіх групах виявлено незначне підвищення фракції викиду, однак зміни були невірогідними і мали лише тенденційний характер (табл.). 
Наступним завданням дослідження був аналіз перебігу захворювання в усіх групах обстежуваних осіб упродовж 12 місяців. Ефективність запропонованих схем терапії оцінювали за такими критеріями ефективності: частота та вираженість загострень, потреба в повторних госпіталізаціях та тривалість ремісій. У пацієнтів I групи частота загострень склала 2,35 $\pm 0,17$ на рік, повторної госпіталізації потребували дев'ять осіб

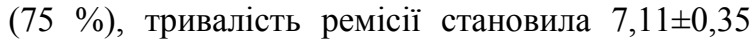
міс. У пацієнтів на тлі прийому дигоксину показники становили $1,85 \pm 0,09$ на рік, дев'ять осіб (60\%) та 8,95 $\pm 0,21$ міс. відповідно, а хомвіокорину $\mathrm{N}-1,91 \pm 0,14$ на рік, 10 осіб $(55,56 \%)$, та 9,14 $\pm 0,32$ місяця. При порівнянні II та III показники між собою суттєво не відрізнялися, проте вірогідно змінювалися порівняно з I групою.

Отже, препарат хомвіокорин-N доцільно призначати пацієнтам із ХСН та ФП на амбулаторному етапі, оскільки при тривалому використанні він покращує самопочуття хворих, зменшує клінічні прояви захворювання, регулює ЧСС, не викликає небажаних побічних ефектів, зменшує потребу в госпіталізації і спрощує контроль лікаря за терапією.

Подальше вивчення нових механізмів дії багатокомпонентного препарату хомвіокорин-N дозволить розширити спектр його використання в терапії, зокрема при мікст-патології внутрішніх органів.

\section{Лiтература}

1. Гланц С. Медико-биологическая статистика / Гланц С.; пер. с англ.; под. ред. Н.Е. Бузикашвили и Д.В. Самойлова. - М.: Практика, 1999. - 459 с.

2. Учебный план для специалистов по сердечной недостаточности Ассоциации по сердечной недостаточности (HFA) Европейского общества кардиологов (ESC) / T.McDonagh, R.S.Gardner, M.Lainscak [et al.] // Серцева недостатність. - 2014. - № 1. - С. 67-80.

3. Balasubramaniam R. Atrial fibrillation in heart failure: the chicken or the egg? / R.Balasubramaniam, P.M.Kistler // Heart. - 2009. - Vol. 95. - P. 535-539.

4. Camm A.J. Atrial fibrillation and risk / A.J. Camm // Clin Cardiol. - 2012. - Vol. 35. - Suppl 1. - P. 1-2.

5. Efficacy of dofetilide in the treatment of atrial fibrillationflutter in patients with reduced left ventricular function: A Danish Investigations of Arrhythmia and Mortality On Dofetilide (DIAMOND) Substudy / O.D.Pedersen, H.Bagger, N.Keller [et al.] // Circulation. - 2001. Vol. 104. - P. 292-296.

6. Heart disease and stroke statistics-2007 update. A Report From the American Heart Association Statistics Committee and Stroke Statistics Subcommittee / W.Rosamond, K.Flegal, G.Friday [et al.] // Circulation. - 2007. Vol. 115. - P. 69-171.

7. Hohnloser S. H.Benefit-risk assessment of current antiarrhythmic drug therapy of atrial fibrillation / S. Hohnloser // Clin Cardiol. - 2012. - Vol. 35. - Suppl 1. P. 28-32.

\section{ИСПОЛЬЗОВАНИЕ КОМБИНИРОВАННЫХ ПРЕПАРАТОВ РАСТИТЕЛЬНОГО ПРОИСХОЖДЕНИЯ ДЛЯ ПРЕДУПРЕЖДЕНИЯ ГОСПИТАЛИЗАЦИЙ ПАЦИЕНТОВ С ХРОНИЧЕСКОЙ СЕРДЕЧНОЙ НЕДОСТАТОЧНОСТЬЮ И ФИБРИЛЛЯЦИЕЙ ПРЕДСЕРДИЙ}

\section{Е.О. Бобкович, Т.А. Илащук, Н.Н. Малкович}

Резюме. Обследовано 45 больных с хронической сердечной недостаточностью (ХCH) IIA-ІІБ стадии III функционального класса и постоянной тахисистолической фибрилляцией предсердий (ФП). Выявлено, что дополнительное назначение хомвиокорина-N способствует более быстрому регрессу клинических симптомов, уменьшению частоты сердечных сокращений, необходимости в повторных госпитализациях, не вызывая нежелательных побочных эффектов. ние.

Ключевые слова: хроническая сердечная недостаточность, фибрилляция предсердий, хомвиокорин-N, лече-

\section{USE OF COMBINED HERBAL MEDICINES TO PREVENT HOSPITALIZATION OF PATIENTS WITH CHRONIC HEART FAILURE AND ATRIAL FIBRILLATION}

\section{K.O. Bobkovych, T.O. Ilashchuk, N.M. Malkovych}

Abstract. Forty five patients with chronic heart failure (CHF) IIA-IIB stage, III functional class and permanent tachysystolic atrial fibrillation (AF) have been studied. It was found that additional prescription of homviokorin-N promotes more rapid regression of clinical symptoms, reduces heart rate and the need for re-hospitalization without unwanted side effects.

Key words: chronic heart failure, atrial fibrillation, homviokorin-N, treatment.

Higher state educational institution of Ukraine «Bukovinian State Medical University (Chernivtsi)

Рецензент - проф. І.А. Плеш

Buk. Med. Herald. - 2015. - Vol. 19, № 4 (76). - P. 19-21

Надійшла до редакції 16.06.2015 року

(c) К.О. Бобкович, Т.О. Ілащук, Н.М. Малкович, 2015 